Холодов А.Ю.

\title{
Психологические и психофизиологические особенности посттравматического стрессового расстройства у шахтеров, пострадавших в результате техногенной аварии*
}

Проблема посттравматических стрессовых расстройств, возникающих в результате техногенных аварий, становится все более актуальной. В последнее время в нашей стране, да и во всем мире, наблюдается увеличение разного рода катастроф. Развивающиеся после чрезвычайных ситуаций психические расстройства иногда значительно затрудняют социально-психологическую адаптацию пострадавших и существенно снижают их трудовую активность.

По данным исследований посттравматическое стрессовое расстройство развивается у 50-80\% переживших тяжелый стресс, а при достаточно высокой интенсивности воздействия может развиться практически у каждого человека. Распространенность ПТСР среди населения колеблется, по разным данным, от 1\% до $67 \%$ с вариативностью, связанной с методами исследования, особенностями популяции, а также, по мнению некоторых авторов, в связи с отсутствием единого четкого подхода к определению диагностических критериев данного расстройства. В мирное время удельный вес случаев ПТСР в ряду других психических расстройств относительно невелик и составляет от 0,5 до 1,2\%. Однако в последние десятилетия в нашей стране, как и во всем мире, отмечается рост количества различного рода катастроф. Это ситуации, характеризующиеся сверхэкстремальным воздействием на психику человека.

В отличие от многих других стрессоров участие в техногенной аварии является пролонгированной психической травмой, т.е. ее последствия могут наступать даже спустя продолжительный период времени. После возвращения к обычной жизни, пострадавшие в техногенных авариях сталкиваются с рядом проблем: дистресс, непонимание со стороны окружающих, нарушения в межличностных контактах, психосоматические расстройства, формирование рентных установок у пострадавших и т.д.

Многообразие способов реагирования на стрессогенную ситуацию и умение человека приспосабливаться к меняющимся условиям имеет под собой биологическую основу. В частности эффективность адаптации связана с включением в этот процесс механизмов регуляции центральной нервной системы. Адаптационная перестройка функций организма связана с изменением сопряженной работы полушарий головного мозга. Поэтому знания типа межполушарной функциональной

* Материалы предоставлены научным руководителем - заведующей лабораторией психофизиологии и экспериментальной психологии ЮФу, доктором психологических наук, профессором Е.В. Воробьевой 
асимметрии у пострадавшего может помочь прогнозировать развитие посттравматического стрессового расстройства и способствовать правильному подбору метода терапии. В психофизиологии в настоящее время проводятся исследования, направленные на поиск связи разных признаков и показателей асимметрии человека с его индивидуальными особенностями и способами реагирования на воздействия среды $[1 ; 2 ; 3]$.

В период с 2003 по 2005 гг. в г. Шахты Ростовской области проводилось исследование пострадавших в результате техногенной аварии и сотрудников поисковоспасательной службы МЧС РФ, участвовавших в ликвидации последствий данной чрезвычайной ситуации. В структуре нарушений, связанных с аварией, одно из первых мест занимают психические расстройства, в частности посттравматическое стрессовое расстройство.

Методологическими и теоретическими предпосылками исследования выступили модели развития ПТСР - психологическая, биологическая и мультифакторная, современные представления о причинах и динамике развития ПТСР, данные изучения физиологических проявлений пограничных психических расстройств, методы психологического и психофизиологического исследования посттравматических стрессовых расстройств. Однако, несмотря на большое число исследований по проблеме посттравматического стрессового расстройства в настоящее время не существует единой общепринятой теоретической концепции, объясняющей этиологию, механизмы возникновения и развития ПТСР.

Следует отметить, что закономерные связи латеральных профилей с некоторыми психическими процессами (например, когнитивными, регуляторными, а также со стилями эмоционального реагирования) уже установлены [1]. В то же время влияние профиля латеральной организации на индивидуальные особенности развития посттравматических стрессовых расстройств все еще остаются недостаточно исследованными.

Таким образом, анализ литературы по проблеме изучения посттравматического стрессового расстройства показывает, что на современном этапе клиническая типология и классификация посттравматического стрессового расстройства (ПТСР), связанного с последствиями тяжелой психической травмы, продолжают уточняться. В эту группу расстройств отнесены затяжные патологические состояния, возникающие у человека после кратковременного или длительного экстремального воздействия. В качестве важных характеристик тяжелого психотравмирующего фактора обозначены неожиданность, стремительный темп развития катастрофического события и длительность воздействия, а также повторяемость в течение жизни.

Помимо тяжести стрессорного фактора важную роль играет уязвимость индивидуума к ПТСР, о которой свидетельствуют не только особенности преморбида (незрелость, астенические черты, гиперсенситивность, зависимость, склонность к чрезмерному контролю, направленному на подавление нежелательной эмоции), но также склонность к виктимизации (тенденции оказываться в роли жертвы при аналогичных ситуациях) или черты травматофилии (удерживание травматического 
опыта). В последнее время все большее значение придается психофизиологическим аспектам стресса, в частности жизненной значимости события, включая отношение личности к угрожающей ситуации с учетом моральных ценностей, религиозного и идеологического мировоззрения. Предрасполагающим фактором может стать физиологическое состояние в момент получения травмы, особенно соматическое истощение на фоне нарушения стереотипа сна и приема пищи.

Проведенное нами эмпирическое исследование показало, что у значительного числа пострадавших в результате воздействия чрезвычайного события на начальной стадии развития посттравматического стрессового расстройства преобладают невротические реакции и выявляются признаки снижения социальной адаптации преимущественно за счет лиц с ЛФА. В дальнейшем у них отмечается стабилизация психического состояния, количественные показатели приближаются к нормативным, у половины испытуемых выявляются признаки компенсации или субкомпенсации. Пострадавшие с ПФА отличаются преобладанием депрессивных состояний с самого начала и тенденцией к нарастанию этих проявлений в дальнейшем. При этом нарастают функциональные расстройства и проявляются психосоматические заболевания.

\section{Литература}

1. Москвин В. А Межполушарные отношения и проблема индивидуальных различий. М.: Изд-во МГУ; Оренбург: Изд-во ИПКОГУ, 2002. 288 с.

2. Тарабрина Н.В., Захарова Д.М., Агарков В А. Психологические особенности посттравматического стресса у спасателей // Материалы IV научно-практической конференции «Посттравматический и поствоенный стресс. Проблемы реабилитации и социальной адаптации участников чрезвычайных ситуаций». Пермь. 1999. С. 7-9.

3. Хомская Е.Д., Батова Н.Я. Мозг и эмоции. Нейропсихологическое исследование. M., 1997. 


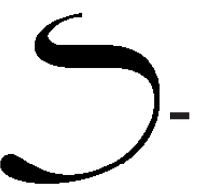

Kholodov A.U.

\section{Psychological and psychophysiological features of posttraumatic stress disorders among miners experi- enced a technogenic catastrophe ${ }^{*}$}

The problem of posttraumatic stress disorders that arise from technogenic catastrophes become more and more urgent. In our country and all over the world there has lately been an increase of different kind of catastrophes. Developing after emergency situations mental disorders significantly aggravate psychosocial adaptation of the injured people and severely reduce their labor activity.

According to research data, posttraumatic stress disorders can be found in 50-80 $\%$ of people suffering from acute stress and if the intensity of the stress is rather high, every person experiences the disorders due to stress. The incidence of PTSD among the population ranges, according to different study results, from $1 \%$ to $67 \%$ of variability, due to different methods of the study, particularities of the population, and in the estimation of some authors, due to the lack of the unique approach of diagnostic criteria of these disorders. In time of peace the incidence of the cases of PTSD among other mental disorders is rather small and ranges from 0,5 to $1,2 \%$.

However in our country as well as all over the world the amount of different kinds of catastrophes has been rising for last decades. These situations are characterized by the extreme impact on man's mentality.

In distinction to many other stressors, the participation in the technogenic catastrophe is a psycho trauma, because its sequences can appear in a long period of time. After returning to everyday life, the injured people face a lot of problems: distress, misunderstanding from the environment, a break of interpersonal contacts, psychosomatic disorders, the formation of indifferent attitudes and etc.

The variety of reactions to stressful situation and the skills of a person to cope with changing environmental conditions have their biological basis. Specifically the efficiency of adaptation is connected to mechanisms of regulation of central nervous system. Adaptative alteration of organism functions depends on changes of the interfacing work of cerebral hemispheres. That's why if we know the type of functional asymmetry, we can forecast the development of the posttraumatic stress disorder and it will help us to choose the right method of the therapy.

Nowadays in psychophysiology they carry out researches directed to find the correlation between different particularities of asymmetry and the indices of the person's asymmetry with his individual features and ways of reaction to environmental impact. $[1 ; 2 ; 3]$

In the period from 2003 to 2005 in town Shakhty of Rostov region we made a

* The article is submitted by the research advisor - the head of the laboratory of Psychophysiology and Experimental Psychology SFU, Doctor of Psychological Science, Professor Vorobieva E.V. 
survey of the people injured after the technogenic catastrophe and the employees of the search and rescue service of EMERCOM (Ministry of the Russian Federation for Civil Defense, Emergency Management and Natural Disasters Response) who took part in the curing the effects of this emergency situation. In the structure of disorders the first place is occupied by mental disorders, especially by posttraumatic stress disorder.

Methodological and theoretical premises of the research are the models of PTSD development-psychological, biological and multi-factor ones, contemporary ideas of causes and dynamics of the development of PTSD, data received through the studies of physiological display of the border-line mental disorders, methods of psychological and psycho physiological research of posttraumatic stress disorders. However in spite of a great number of researches concerning posttraumatic stress disorders, there is no unique generally accepted conception, explaining the etiology and mechanisms of the origin and development of PTSD.

It is necessary to underline, that regular links of lateral profiles with some mental processes (for instance, cognitive, regulatory and other styles of emotional reactions) have been established[1]. At the same time the influence of profile of lateral organization upon individual particularities of development of posttraumatic stress disorders seem not to be enough studied.

So, the analysis of literature on the problem of posttraumatic stress disorders show that at the contemporary stage the clinical typology and classification of posttraumatic stress disorders connected to consequences of a heavy psycho trauma are still under analysis. Long posttraumatic pathological states, that appear after short- or long-term extreme impact are assigned to this particular group. As the very important characteristics of a heavy psycho traumatic factor they indicate the unexpectedness, the violent onslaught of the development of the catastrophe and the duration of the pressure, as well as the repeatability at the lifetime.

Apart from the hard influence of the stressor, the sensitivity of the individual to PTSD plays a very important role, that is not only testified by such particularities as the immaturity, asthenic traits, hypersensitivity, dependence, aptitude to excessive control, desire to overwhelm unwilling emotion, but among other the victimization attitude (the tendency to become a victim in the corresponding situation) or traits of traumaphil (retention of traumatic experience). They have lately attached the importance to psycho physiological aspects of stress, particularly to the life significance of the event, including the personal attitude to the threatening situation taking into account moral values, religious and ideological world outlook. The physiological state during the catastrophe, especially somatic deterioration on the back of sleeping and eating difficulties, can be a predisposing factor.

The carried out empirical research showed that the significant number of the injured people in the consequence of the emergency situation, experiencing neurotic reactions and displaying the signs of decrease of the social adaptation at the first stage of the development of posttraumatic stress disorders, are the people with left functional asymmetry. Hereafter we could register stabilization of mental state, quan- 
tity indices are near the mark, a half of respondents displayed the traces of the compensation and subcompensation. The injured people with RFA contrast by depressive state from the very beginning and the tendency of the increase of these states further. Herewith they demonstrate functional disorders and psychosomatic diseases.

\section{THE LITERATURE}

1. Moskvin V.A. Interhemispheric relations and the problem of individual particularities. M.: Publishing house of MSU; Orenbourg: Publishing house of IPR OSU, 2002. 288 p.

2. Tarabrina N.V., Zakharova D.M., Agarkov V.A. Psychological features of posttraumatic stress of rescuers // Materials of IV scientific practical conference "Posttraumatic and postwar stress. Problems of rehabilitation and social adaptation of participants of emergency situations". Perm. 1999. p. 7-9.

3. Khomskay E.D., Batova N. Y. Brain and emotions. Neuropsychological research. M., 1997. 